\title{
De-'Moor’ Tifying Shakespeare’s Othello: Iago as a Renaissance Form of Islamophobia
}

\author{
Hanita Hanim Ismail ${ }^{1}$, Arbaayah Ali Termizi ${ }^{2} \&$ Radzuwan Ab Rashid ${ }^{1}$ \\ ${ }^{1}$ Universiti Sultan Zainal Abidin, Kuala Terengganu, Terengganu, Malaysia \\ ${ }^{2}$ University Putra Malaysia, Serdang, Selangor, Malaysia \\ Correspondence: Hanita Hanim Ismail, Centre of English Language Studies, Faculty of Languages and \\ Communication, Universiti Sultan Zainal Abidin, Kuala Terengganu, Terengganu, Malaysia. E-mail: \\ hanitaismail@unisza.edu.my
}

Received: May 23, 2018 Accepted: June 20, 2018 Online Published: November 27, 2018

doi:10.5539/ijel.v8n7p23 URL: https://doi.org/10.5539/ijel.v8n7p23

\begin{abstract}
Albeit Othello's loyal service to Venice is clear, ramifications of the Blackamoor in the text has called upon a continuous scholarship of interest over the last two decades. One begins to wonder, whether the Blackamoor's presence in a Venetian setting serves a purpose to the English readership? If so, to what extent did Shakespeare refine the representation of a Moor to draw upon readership? How does Iago serve as a propagandist who articulates and fuels concerns for the seventeenth-century version of Islamophobia? As such, these significant questions have led to the construction of this paper, since these issues continuously problematize and make relevance of Shakespearean plays in the contemporary world. As such, this article examines the significance of Shakespeare's inclusion, portrayal and representation of Othello as a Moor that poses an image of threat in a seventeenth-century Western context. At the same time, this paper also asserts that Iago is the mouthpiece who initiates worries over possible threats of Islamophobia. The use of Greenblatt's New Historicism, particularly his concept of energia (1988) enables the validation of such claims by making relevance of the Battle of Lepanto (1571). Results indicated that 'Othello' provides an important platform to discuss contemporary renaissance issues such as Islamophobia and Englishness, through indicative clues that Iago is the mastermind that causes fear of the advancing Moors.
\end{abstract}

Keywords: Islamophobia, Iago, Othello, Shakespearean plays, religious identity

\section{Introduction}

Shakespeare's Othello generally depicts the tragedy of an obedient naval captain's love for his new country, Venice but after careful reading, it reveals layers of its complexity, especially one that concerns characterization and possibly a suggestion of propaganda. Some see the irrelevance of uncovering politico-religious discussions in this play (e.g., Loomba, 2001). Yet, this paper aims to explore and understand the significance of portraying and representing Othello as a Moor in a seventeenth century context; by situating him in an imagined setting-Venice, he is deemed a threat to Western Christian civilisation. At the same time, this paper also asserts that Iago is the mouthpiece who initiates fear over possible threats of Islamophobia.

Many assume that Othello is the only character that encounters a face-off between the Western civilization and Muslim Empire. Such innuendoes were suggested through a well-known painting of Mueley Hamit in 1600, - a public figure known to be an acquaintance of Elizabeth I (Harris, 1958; Matar, 1998). The identity of this Muslim figure remains questionable. However, Vaughn (2005) claimed that the figure was the ambassador Abd el-Ouahed ben Messaoud (Figure 1). Either way, this familiar portraiture signals an established diplomatic and political relationship between the Muslim world and the English during the reign of Elizabeth I, which unlikely was the same during the reign of King James. Despite James's political policy regarding the Muslims, he expressed firm discontentment against them. 


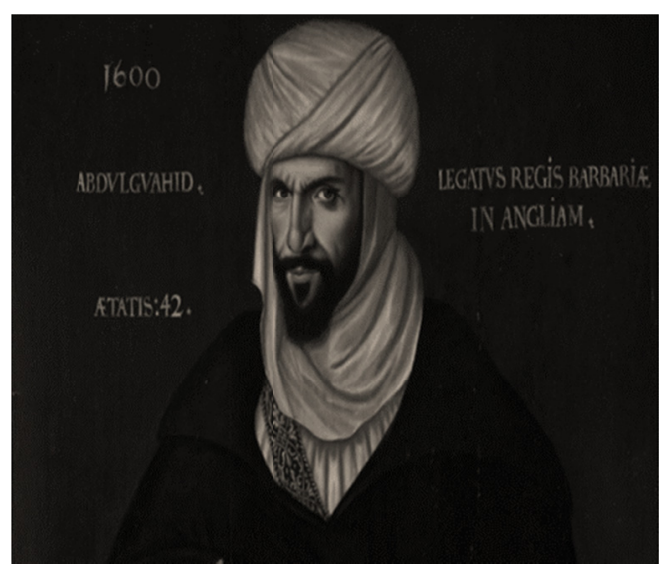

Figure 1. Painting of Mueley Hamit (Google)

This however, is not entirely true. There were earlier mentions and reported presence of the tawny faces in England. Before the romance between Othello and Desdemona was staged in 1604 (Loehlin, n.d.), the public was informed of Orlando Furioso (1532) - an Italian poem about a converted Saracen named Ruggiero who married a Christian lady (Robinson, 2007). There were other claims of Native West Africans being shipped to England as part of the slave trade in 1554 (Cowhig, 1987). They were prisoners of war who were then enslaved, with chains and cuffs over their hands and feet. In fact, there were also reports about Francis Drake who brought home thousands of slaves in 1568, some of whom were later baptised in order to avoid persecution. Muslims then were often referred to as the Saracens, as those portrayed in Marlowe's Tamburlaine the Great (1587). They were mainly perceived as evil and untrustworthy. They were Evil in human disguise (if not "semihomos", instead of homosapiens (Hunter, 1978), which explains the lack of contestation over the issue of skin colour until the eighteenth century. It was then that the portrayal of a Moor became more complex; either described as one with tawny skin-colour or having a certain Arabic background, unlike before, which Cowhig (1979) pointed out its lack of controversy. This is because stage actors like James Quin and David Garrick mainly blackened themselves in their performances. These actors transformed themselves into Negroes, instead of Arabs. Later, stage actor Edmund Kean presented himself as an Arab Moor in 1814. This misrepresentation of race is addressed by Cowhig (1977), who identified a strong practice of categorizing the black as either villain or villain-hero, in which Othello is an example.

Colour prejudice in the European world was already in existence then. The earliest records of xenophobia dated back to the time of Erasmus, when he wrote widely on the Turks in the 1530s, cautioning Christians against behaving like the Turks. He was also under the patronage of Charles V, who championed crusades (either internally or externally) against threats posed by the Turks-a reference that replaced the term Saracens (Dimmock, 2005). England's national policy shifted between governance, where Charles V and Henry saw a need to go to war with the advancing Ottoman Empire, seeing it as a "humanist obligation" to defend the sanctity of Christendom (Dimmock, 2005, p. 22). To the West, the Turks were barbaric - a description that is rooted in reference to the Barbary Coasts corsairs of the seventeenth century or better known as Barbary demonic pirates, ruthless at conquering the world. They were a separate entity from the Ottoman Empire (Tinniswood, 2011). This state of fear towards the Muslims has not changed much; it remains political to this day although not as obvious now as it was then. As such, Shakespeare's representation of Othello as a blackamoor or as a Turk amply sends out a message of threat, which was appropriate during that period since the Ottoman Empire was advancing within the region of Venice. This explains the unabated interest in portraying Othello as a threat via his politico-religious identity. Orkin (1987) clearly identified colour prejudice that appears in Othello through Iago's insinuation against the blackamoor's position and good image.

Scholars have approached Othello mainly in two phases. The first wave of interest mainly focused on establishing an understanding of Othello's skin colour, associating the character to the Negro's physical attributes, if not as a binary opposite to the white people (e.g., Butcher 1957; Fiedler 1972; Hunter 1978). The first contention on Othello's racial background was initiated by Butcher (1957) when he specifically associated the term 'Moor' to being black - an initial term associated with evil. Fiedler (1972) and Hunter (1978) both emphasized the significance of understanding Othello as a representation of the Devil, associating colour with virtue. Hunter's (1978) argument is based on the currency of perspective on Renaissance studies which are 
viable for current examination since issues regarding black/white and good/evil are postmodern topics. Similarly, Fielder (1972) viewed such issues as an effort to further understand human nature. While this is old news, it remains relevant since the complexity associated with Othello's skin colour will determine many other factors like religious-political matters and their effects on societal perception, reception and attitude towards a foreign entity such as Othello himself. There were also those who refused to take sides; Othello was neither black nor Moor (Goddard, 1974).

The second wave of interest saw researchers who argued for different concerns (e.g., Hall, 1991; Boose, 1994; Vitkus, 1997; Neill, 1998; Loomba, 1998, 2001). While Boose (1994) promoted the inclusion of religious-political perceptions because most expansions were likely to involve interests over religion and politics, both Loomba and Neill took on a more secular approach. Loomba (1998) voted against the necessity to even dwell into the study of the blackamoor's skin colour, and Neill (1998) worked at constructing the idea of duality at defining Othello's identity where colour, according to him, does not equate to singularity of religion. Hence, he argued that a coloured man can also be a religious Christian. In short, there were divided opinions about Othello's skin colour, whether he is black or tawny and this confusion arises due to several reasons. Cowhig (1985) explained that it was due to the mixed reactions and attitude concerning a foreign entity in English soil during the sixteenth century. Some found the unfamiliar to be an exotic object. Yet, the uncertainty over the Moor's skin colour has garnered a plethora of reactions among the scholars, especially if Othello's religion is included (Bartels, 1990).

While understanding Othello as a subject matter remains an ongoing interest, Iago's image as a culprit is also given equal attention (e.g., Scragg, 1968; Rand, 1950; Coleridge, 1974). Another school of thought believes in Iago's innocence. Iago merely reports what he knows of Othello's emotions (Taylor, 2004), so what then, if this is not the behaviour of another typical man who has a natural slant for evil doings (Draper, 1931). In favouring Iago, Wangh (1950) perceived that Iago's evil slant is due to his homosexual jealousy over Othello's marriage. All of these provide a glimpse of the opposite of the Other which yields upon scrutiny, since its scholarship creates an awareness of examining the Self, instead of the Other. Another approach at perceiving Iago is taken from the Islamic point of view where in a subsection of her book, Nor Faridah Abdul Manaf (2004) referred to Iago as an example of one of Al-Ghazali's division of human states, the natural state or al-Nafs al-Ammarah (the self that incites evil). Hunter (1978) indirectly drew upon the need to focus on Iago, instead of Othello; despite his white appearance, his inner flaws caution us to look beyond exterior presentation. His unwavering determination to destroy Othello without any reason makes him evil. This insatiable desire to do evil is seen in other aspects that project Iago as an agent of evil. One aspect is highlighted by Adelman (1997) where like the Devil, Iago is a master at splitting others, either as seen in Othello and Desdemona's marriage or among the Venetians concerning Othello's loyalty. It is Iago who initiates the labelling of blackness against white. And like the Devil, dying too isn't an option for Iago since he only bleeds, instead of passing on to the other world. Indeed, the inclusion of Iago in Othello is allegorical, as suggested by Scragg (1968) but one wonders, whether Iago's allegorical representation of evil is aimed at making fun of the Christendom's role in the modern religious-political landscape.

Another recent scholarship query is on Venice, which also plays a heightened source of energia at providing a platform for locating discussions and people of the time, and one of the sub-questions that appeared is Shakespeare's presence in the city (Tosi \& Bassi, 2011). The query on setting selection, and its significance and contribution towards issues discussed at that time, calls upon some attention since Shakespeare must have considered its role in the inclusion.

This exploratory study remains significant and contributes as a reminder at providing vitality and continuity in (re)reading past literary texts, especially in Shakespearean works. As such, this paper aims to explore the significance of Othello's presence in a Venetian setting in relevance to the English audience. If so, did Shakespeare refine the Moor's representation to attract readership? Finally, how does Iago serve as a propagandist who articulates and fuels concerns for a seventeenth-century version of Islamophobia? By acknowledging existing fear towards Islam in a seventeenth-century historical landscape, comprehending Othello becomes easier especially the range of its acts represented by Iago, in order to preserve order in a Modern European context. This is because discrimination against those who practise Islam as a religion, has long existed in history and although the term Islamophobia is relatively new, its practice has not ceased. The representation of Othello as a coloured captain may or may not have arisen from Islamophobia during the seventeenth century but this needs to be explored further. 


\section{Theoretical Framework}

In order to excavate the dead and establish a correlation between the portrayal of Othello as a Moor and the contemporary fear for Islam, it is most apt to uncover the contextual layout of the period. Since no text is near perfection nor embodies the idea of "freestanding container of all its meaning", Greenblatt (1988) suggested a constant "negotiation" in the effort to interpret textual meaning, especially in reading any Shakespearean plays. This recommendation shapes the making of the poetics of culture which is founded on the idea of energia. An energia can range from a specific event, person or object mentioned in a text, that can act as the central force which certifies the popularity of such literary text, even if it surpasses time. This is so, Greenblatt explained, because there is an existing cultural context that surrounds the author's writing experience, which eventually influences the textual meaning-making. Indirectly, this hints upon the need to use historical reading at deciphering meaning. Such energia prompts readers' immediate association (or otherwise) with an event/person/object in a historical timeline.

Cohen (2007) observed that the use of New Historicism makes relevance of historical perspectives by making "synchronic of a historical product" where the present interpretation contributes towards an understanding of the past by giving it a continuous assessment of meaning. This provides an avenue for continuous revisiting and rereading of literary texts that will outlive its writing context, and this is one of the several advantages that New Historicism offers to literary criticism. Readers are able to relate to the writer's authorial intention, having understood the context that promotes its production. However, Greenblatt's proposal is also seen as valid, due to the subjectivity of historiography and the historian's individual preference and perception in analysis. Howard (1986), for example, contested that, a "unified truth" is far-fetched since New Historicism involves many readings of the past which truth is uncertified. Not only is truth uncertain, the question of whose version is to be accepted will also surface. Another recent criticism against New Historicism underlines the lack of specialization if historical approach is to be applied in literary criticism (During, 1991).

Albeit difference of opinions with regards to its relevance and contribution to the field of literary criticism abound, New Historicism is deemed to be effective at striking a conversation between the dead and the living. Fiorentino, in his series of sources on Shakespearean works (1957-1975) as well as Salinger (1993), mutually observed how the contextual surroundings are influential at moulding their opinion, and this plays a role in affecting the more contemporary readers. New Historicists are agents of past ideologies, who reinvigorate these in the hope of helping readers to further understand the dead writers, especially their authorial intentions.

\section{Results and Discussion}

\subsection{New Historicism on Venice and Lepanto: Othello's Politico-Religious Significance}

My assertion of Othello as a contemporary fear is based on the tone of discussion between the Venetian duke and his senators, on the urgency to send immediate naval assistance to the sea battle in Othello. This is a direct indication of a specific preparation for the Battle of Lepanto (1571), which is an example of Greenblatt's energia. The battle is mainly made up of several campaigns but in the play, a portion of the battle features the Venetians being immediately summoned to assist in the efforts to barricade the Turks from advancing into Cyprus. At the same time, the duke and his band of senators recommend immediate naval support, led by Othello himself. The Ottoman Empire posed the biggest threat to the Holy Roman Empire and Christendom. The Turkish expansion quickly took the world by surprise where Bicheno (2003) described the campaign to decapitate the Christians' effort of winning any battle before Lepanto, thus demoralizing the Christians. Invincibility of the Turks created anxiety that further jeopardized their confidence. This is the associating factor that links the text to the battle.

In history, Venice was known to be the financial benefactor and supplier of manpower to Christendom (Bridges 1935). The Turks' canniness at military advancement, however, is put to question when it comes to sea battle. The image of a tempest (1.3.1-47) suggests uncertainty. Shakespeare describes in great length, the final cause that leads to the defeat of the Ottomans: the Bard crafts a great "tempest" as a metaphor of anxiety that finally "hath so banged the Turks/That their designment halts" and brings about "wrack and sufferance ... of their fleet" (2.1.21-24). The nature of a tempest equates to rumours, where uncertainty lingers, as shown in the first fifty-five lines in the first scene of the Second Act, implying that triumph is now questionable between the two sides. In reality, the final phase of the Battle of Lepanto is won by the Christians through Doria and Padilla - the two commanding officers of the Christian fleet, who used the 'fence-in' strategy to drive the Ottoman Right Wing to crash into the island of Oxia, an island near Lepanto. Like the tempest, witnesses to this incident could not tell for certain as to who had won, as surrounding ships saw heavy clashes of artillery amid huge splashes of water, enveloped by thick clouds of smoke; they passed this spectacle before anyone was able to identify the victor or the vanquished. This triumphant event was further announced in other seventeenth-century 
contemporary literary works, such as Rufo's La Austriada (1582) and Zuniga's La Araucana (1569; 1570; 1578), indicating great pride over the battle where a similar celebratory hue is included in the play: "Upon certain tidings now arrived, importing the mere, perdition of the Turkish fleet, every man puts himself into triumph: some to dance, some to make bonfire" (2.2.2-4). Even King James wrote a poem in celebration of the event where Jones (1968) associated the currency of the event to the bard's yielding to impress the monarch. These records of celebration of victory brought forth conflicting opinions: some argued its significance as a religious-political outlook on Lepanto. This then came to be seen as early modern historical event that fuelled a crucial discussion (e.g., Jones 1968; Boose 1994; Everett 2000; Malieckal 2000). There were also others who contested its relevancy (e.g., Braxton 1990; Shuger 1996).

Yet, the specificity of these two events with reference to the battle further validates a connection between Lepanto and the battle referred to in the play. The first is conveyed through the portrayal of the Turkish galleys between Rhodes and Cyprus (1.3.1-43) where their movement is said to be fickle. This to-and-fro motion causes confusion among the board of Venetian governance, since messengers reported massive activities of Turkish fleets (2.1.20-24) and it is in parallel with historical recordings. Turkish battleships hovered around the edges of the southern parts, nearer to the Mediterranean Sea in 1571, which Shakespeare re-enacts in Othello in the first announcement of the Turkish advancement, calling for the immediate need for naval assistance. At the point of his entrance in the third scene of the First Act, the duke is puzzled by the inconsistent number of ships in his reports, which varies from a count of "a hundred and seven galleys" to an increase of another thirty-seven. Finally, the third senator adds to this uncertainty, claiming "two hundred" according to his informer (1.3.1-4). The state of uncertainty raises tactical panic among the Venetian leaders as evident from the short exchange of dialogue pertaining to this ambiguity (1.3.1-45). Despite the illustrated distance before battling it out at Lepanto (Figure 1), the Venetian fleet encountered its opponent next to Curzolari isle. This is further testimonial to the Turks' defeat - a common historical fact that acknowledges their lack of savvy over the condition of the Venetian coastal landscape. Bicheno (2003) depicted the Turks' galleys as tall and narrow while the Venetians have light galleys, providing them with quick shifts of directions (see Figure 3). The seating of these Venetians rowers also benefited easy manoeuvring along the shallow shores, as against rocky streams. Bicheno described the scenario where "During the final phase of the Ottoman defeat the defining factor for those that managed to escape was the degree to which they were able to sail into westerly breeze ... Uluch Ali led the way towards the gap between Khoutsilaris and Ocia islands, with the group led by Doria conducting lateral pursuit and preventing from tacking away to the south-west. Padilla's squadron of Naples galleys ... now rowed to close this gap, forcing Uluch Ali's group to point further into the wind ... only a well-handled galley employing quarter rowing could match the performance of the galliot into the wind, and those that could were trapped between Doria, Padilla and the island of Oxia" (275-277). Figure 2 illustrates the ability of the Venetian galleons to specifically steer from one island to another, whereas the Ottoman galleys manoeuvred directly from an outer region into the local shores.

Besides the Battle of Lepanto, the worthiness of including Venice as a seventeenth-century setting in any English plays, particularly those by Shakespeare, highlights an acknowledgement of the city-state as important, both affecting meaning-making in general and specifically, thematic inspiration. It was the centre of the world (Perroco, 2011) and Shakespeare was commonly known to be influenced by contemporary issues around him and the Englishmen. Of course, Wells (2011) provided a connection to this awareness, explaining that even if Shakespeare had not physically been to Venice, he was well-informed through reading materials, networking and the common knowledge about the city. Perocco (2011) specifically associated several novellas with charming Venetian settings that might have inspired the Bard of the city. Wells (2011) argued that the city-state was romanticised as a space that allowed the impossible, since it was looked up to as a state of political or financial reference, occupying centrality within the English imagination (Perocco 2011; Hadfield 2011), hence providing a conclusion that Shakespeare was not far from the currency of this knowledge. To the English, Venice and its political as well as social setup are looked up to as perfect examples. Perocco (2011) described this common fascination among the English as an outlet for imaginary escape out of what is impossible. McPherson (1990), however, rationalized that Shakespeare's inclusion and presentation of Venice as the land of pleasure, is one of the known functions of the Myth of Venice.

Apart from Cyprus, Othello is set in Venice where law is upheld to govern the city-state. The effective-working duke and his band of senators illustrate a regulated space where law is practised. The public listen to the orders given by these governors, indicating that law is respected. Because Othello stands out among the crowd, it can be assumed that Venice is filled with white people. From the description of Venice, the city-state was also known to be popular for its prostitution and promiscuity. Unlike the Venice featured in Othello, Venice in Merchant of 
Venice is described luminously for its wealth and breezy seaside with obvious shipping facilities. The city-state was thus shaped in a way to fit the trading lifestyle, which situates the Jew and his business surroundings.

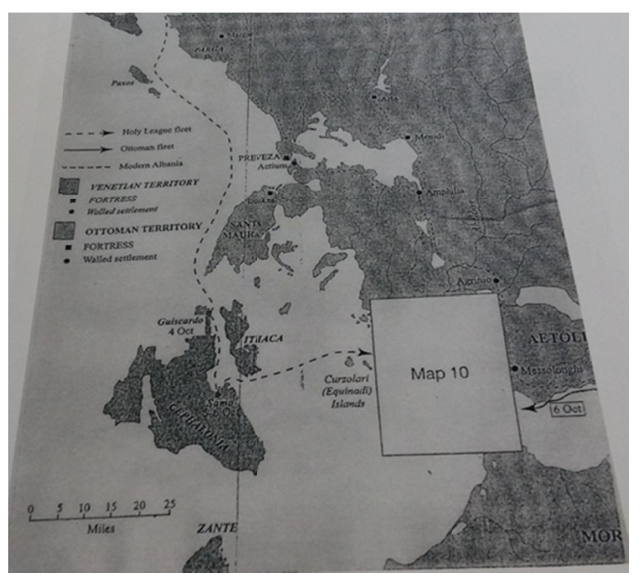

Figure 2. Map depicting War Route during the battle of Lepanto (Bicheno 2003)

It is through the use of New Historicism that one would be able to make a link between such a crucial historical event and its inclusive role as a religious-political trigger that is embedded within this play. Therefore, prior knowledge of the seventeenth-century Turks and Christians' political dynamics and current affairs helps the effective reading of the play, framing it in its historical, contextual understanding.

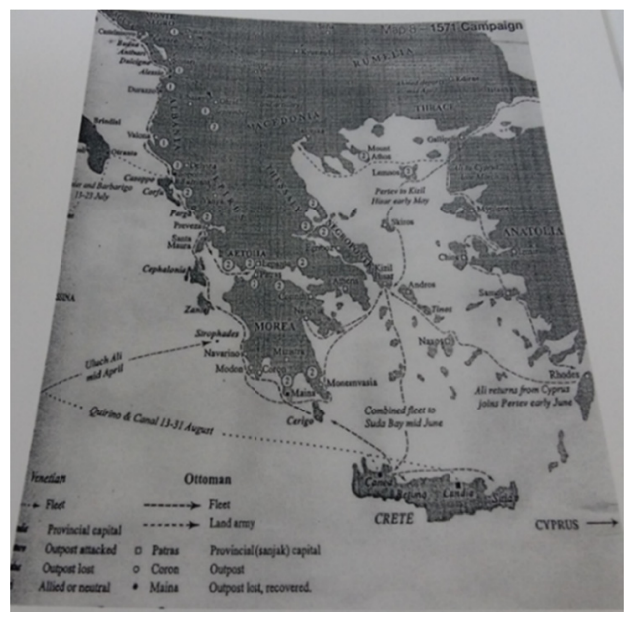

Figure 3. The 1571 Campaign (Bicheno 2003)

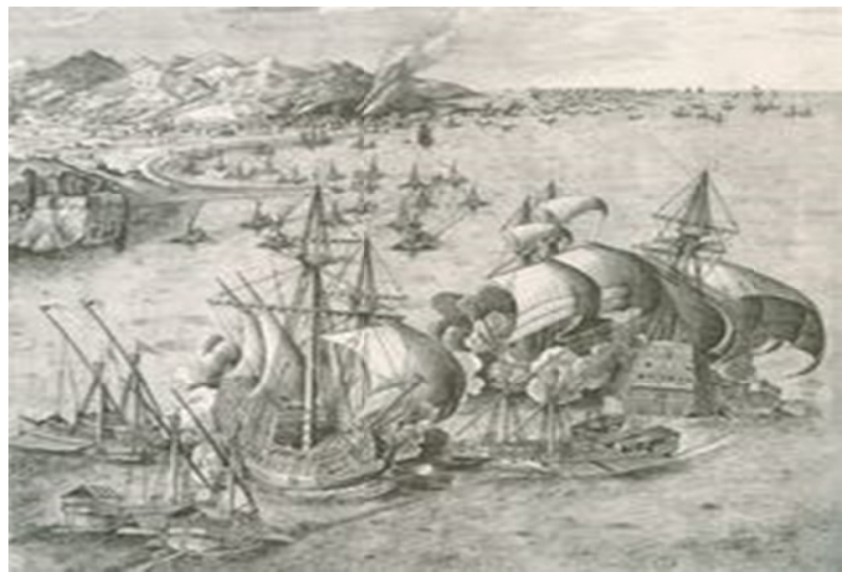

Figure 4. Bruegel's Depiction of Galleys attacking Galleons (Bicheno 2003) 


\subsection{Iago as a Propagandist}

The celebratory demeanour of the duke and his band of senators upon learning of their triumphs in the battle however, is interrupted by Iago who insinuates that Othello wears an insider's disguise, one claiming to be a friend but who instead serves the foe. Although an immediate perception of the inclusion of the variable religion hints at Islamophobia, the Moor's presence plays a far more crucial role over national sentiment and identity. Iago plays a role that fuels hatred against Othello, devising several ways of portraying an image of threat, which simultaneously suggests a form of Islamophobia. The disappointed Venetian serves to present a significant role which reminds the readers of a national concern. He serves as a mouthpiece that emphasizes nationhood and Englishness. Although such issues might not have appeared within an early modern timeframe, there are concerns that support this.

Jealousy is a common factor that adds to the dilemma in this play, which many agree upon (e.g., Everett, 2000). While associating Othello's enviousness and his act of murdering Desdemona as an act of profound jealousy, there is another level of jealousy included in this play; one that is cunning enough to provoke others at doing evil. Such malice is exhibited by Iago, whose "poisonous mineral" nags from within (2:1.295). Iago's successful act of spreading propaganda to destroy Othello manifests in the blackamoor's burgeoning jealousy of Desdemona, that turns him into a "green-eyed monster" (3:3:168). Not only is Iago capable of creating doubt within Othello of Desdemona's fidelity through his effective use of propaganda, he is also clever at striking fear among the senators on the false pretext of pledging loyalty towards Venice, by revealing the blackamoor's past.

Iago's role isn't as secondary as one assumes him to be; Adelman (1997) argued that the play gains its fame not for the blackamoor; it "begins with Iago" (125). It is Iago, besides Roderigo, who provides descriptions of Othello at the beginning of the play. Iago's role in the play is to highlight racial discrimination and its danger to Venice and its community. Like the black presence in Europe during the sixteenth and seventeenth century, Othello poses a danger that signals a clear warning. In fact, the fuzziness of his skin colour could have been tactical in order to emphasize the biblical worry over the black, and this is underscores the dangers of religious turmoil posed by the advancing Ottoman Empire.

\section{Conclusion}

Shakespeare's Othello prompts synchronous discussions of a contemporary issue, namely Islamophobia. It is framed in a historical event and is further magnified through worries articulated by Iago, who does not only operate as the mastermind who causes fear of the advancing Moors, but is also the propagandist who executes its mechanics. This research discusses how the play expresses contemporary fear over an empire for its fast-growing politico-religious influence, and which includes a character with a cunning ploy to curtail the advancement of his counterpart. This discussion is relevant to understanding the present worldview regarding Islamophobia and its evolution, in that it facilitates primary understanding of how it is not a new phenomenon but merely something that is spurred by a small flicker of jealousy.

\section{Acknowledgement}

This research was partially inspired by my M.A. thesis entitled "Shakespeare's Othello: Religious Identity and Englishness" (2008) under the supervision of the late Prof. Lim Chee Seng whose passion shone the brightest in Shakespearean studies. His scholarship in Shakespearean studies remained relevant, especially during his last few years of service in University Malaya. Sources retrieved for the benefit of this article mainly came from the library of University Putra Malaysia. It was then presented as a paper in the 9th Malaysian International Conference in Languages, Literature and Culture between the 16th and 18th August 2016. Upon receiving several comments from the audience and sharing thoughts among colleagues, the paper is improved of its approach. Special thanks go to Bicheno for granting permission to use his maps which were an invaluable source of information towards understanding the Battle of Lepanto.

\section{References}

Adelman, J. (1997). Iago's Alter Ego: Race as Projection in Othello. Shakespeare Quarterly, 48(2), 125-144. https://doi.org/10.2307/2871277

Bartels, E. (1990). Making More of the Moor: Aaron, Othello and Renaissance Refashioning of Race. Shakespeare Quarterly, 41(4), 433-454. https://doi.org/10.2307/2870775

Bicheno, H. (2003). The 1571 Campaign. In Crescent and Cross: The Battle of Lepanto 1571. London: Cassell.

Boose, L. (1994). The Getting of a Lawful Race. In M. Hendricks \& P. Parker (Eds.), Women, 'Race' and Writing in the Early Modern Period (pp. 35-54). London \& New York. 
Braxton, P. N. (1990). The Moor and the Metaphor. South Atlantic Review, 55(4), 1-10. https://doi.org/10.2307/3200442

Bridges, A. (1935). Suleiman the Magnificient: Scour age of Heaven. Granada: Herts \& London.

Butcher, P. (1952). Othello's Racial Identity. Shakespeare Quarterly, 3(3), 243-247. https://doi.org/10.2307/2866304

Cohen, S. (2007). Introduction. Shakespeare and Historical Formalism. By Cohen. 13 July 2007.

Coleridge, S. (1971). Coleridge on Shakespeare: The Text of the lectures of 1811-12. R. A. Foakes (Ed.). London: Routledge and K. Paul.

Coleridge, S. (1974). Shakespearean Criticism (Vol. 1). T. M. Raysor (Ed.). London: Dent.

Cowhig, R. (1977). The importance of Othello's Race. The Journal of Commonwealth Literature, 12(2), 153-161. https://doi.org/10.1177/002198947701200212

Cowhig, R. (1979). Actors, Black and Tawny, in the role of Othello, and their critics. Theatre Research International, 4(2), 133-146. https://doi.org/10.1017/S030788330 0000262

Cowhig, R. (1985). The Blacks in English Renaissance drama and the role of Shakespeare's Othello. In D. Dabydeen (Ed.), The Black Presence in English Literature (pp. 1-23). Manchester: Manchester U.P.

Dimmock, M. (2005). New Turkes: Dramatizing Islam and the Ottoman in Early Modern England. England \& Burlington: Ashgate.

Draper, J. W. (1931). Honest Iago. PMLA, 46(3), 724-735. https://doi.org/10.2307/457857

During, S. (1991). New Historicism. Text and Performance Quarterly, 11(3), 171-189. https://doi.org/10.1080/10462939109366008

Everett, B. (2000). Inside Othello. Shakespeare Survey, 53, 184-195. https://doi.org/10.1017/CCOL0521781140.016

Fiedler, L. (1972). The Stranger in Shakespeare. New York: Stein \& Day.

Fiorentino, G. (1957-1975). II pecorone. Geoffrey Bullough (Trans.). In G. Bullough (Ed.), Narrative and Dramatic Sources of Shakespeare (vol. 8, pp. 463-476). London: Routledge and Paul.

Goddard, H. C. (1974). Alphabet of the Imagination. E. G. Worthen \& M. G. Holt (Eds.). Humanities Press: New Jersey.

Greenblatt, S. (1988). Introduction. In "The Forms of Power and Power of Forms in Renaissance." Genre, 15, 3-6.

Hadfield, A. (2011). Shakespeare and Republican Venice. In Visions of Venice in Shakespeare (pp. 67-82). Ashgate: Surrey.

Hall, K. (1991). Sexual Politics and Cultural Identity in the Masque of Blackness. In S.-E. Case \& J. Reinelt (Eds.), The Performance of Power: Theatrical Discourse and Power. https://doi.org/10.2307/j.ctt20h6tv1.4

Harris, B. (1958). A Portrait of Moor. Shakespeare Survey, 11, 89-97. https://doi.org/10.1017/CCOL0521064244.009

Howard, J. (1986). The New Historicism in Renaissance Studies. English Literary Renaissance, 16, 13-43. https://doi.org/10.1111/j.1475-6757.1986.tb00896.x

Hunter, G. K. (1978). Othello and Colour of Prejudice. In Dramatic Identities and Cultural Tradition: Studies in Shakespeare \& His Contemporaries (pp. 30-59). Liverpool: Liverpool U.P.

Jones, E. (1968). Othello, Lepanto and the Cyprus War. Shakespeare Survey, 21, 47-52.

Loehlin, J. (n.d.). Othello, a stage History. Not even past. Retrieved from https://notevenpast.org/ourstories/othello-a-stage-history/

Loomba, A. (1998). Colonialism/Postcolonialism. London \& New York: Routledge.

Loomba, A. (2001). Outsiders in Shakespeare's England. In M. de Grazia \& S. Wells (Eds.), The Cambridge Companion to Shakespeare (pp. 147-157). Cambridge \& New York: Cambridge U.P. https://doi.org/10.1017/CCOL0521650941.010

Malieckal, B. (2000). Treason of the Blood: Race and Blood in English Renaissance Drama. Diss. Baylor University. Ann Arbour: UMI. 
Marrapodi, M., Oenselaars, A. J., Cappuzzo, M., \& Santucci, L. F. (Eds.). (1993). Shakespeare's Italy: Functions of Italian locations in Renaissance drama (pp. 171-184). Manchester \& New York: Manchester U.P.

Mattar, N. (1998). Islam in Britain: 1558-1685. New York: Columbia U.P. https://doi.org/10.1017/CBO9780511582738

McPherson, D. C. (1990). Shakespeare, Jonson and the Myth of Venice. Newark: University of Delware Press.

Neill, M. (1998). "Mulattos", "Blacks" and "Indian Moors": Othello and Early Modern Construction of Human Differences. Shakespeare Quarterly, 49, 361-365. https://doi.org/10.2307/2902233

Nor Faridah Abdul Manaf. (2004). An Islamic Interpretation of Tragic Hero in Shakespearean Tragedies. Kuala Lumpur: International Islamic University Malaysia.

Orkin, M. (1987). Othello and the plain face of Racism. Shakespeare Quarterly, 38(2), 166-188. https://doi.org/10.2307/2870559

Perocco, D. (2011). Venice, Shakespeare and the Italian Novella. In L. Tosi \& S. Bassi (Eds.), Visions of Venice in Shakespeare (pp. 33-46). Ashgate: Surrey.

Rand, F. P. (1950). The Over Garrulous Iago. Shakespeare Quarterly, 1(3), 154-161. https://doi.org/10.2307/2866423

Salinger, L. (1993). The Idea of Venice in Shakespeare and Ben Johnson. In M. Marrapodi et al. (Eds.), Shakespeare's Italy: Functions of Italian locations in Renaissance drama (pp. 171-184). Manchester \& New York: Manchester U.P.

Scragg, L. (1968). Iago-Vice or Devil. In K. Muir (Ed.), Shakespeare Survey: An annual survey of Shakespearean study and production (pp. 53-65).

Shuger, D. (1996). Subversive Fathers and Suffering Subjects: Shakespeare and Christianity. In D. B. Hamilton \& R. Strier (Eds.), Religion, Literature and Politics in Post-Reformation England, 1540-1688 (pp. 46-69). Cambridge: Cambridge U.P. https://doi.org/10.1017/CBO9780511518928.004

Taylor, J. S. (2004). Autonomy and Informed Consent: A Much Misunderstood. The Journal of Value Inquiry, 38, 383-391. https://doi.org/10.1007/s10790-005-5868-8

Tinniswood, A. (2011). Pirates of Barbary: Corsairs, Conquests and Captivity in the $17^{\text {th }}$ Century. Vintace: London.

Tosi, L., \& Bassi, S. (2011). Visions of Venice in Shakespeare. Ashgate: Surrey.

Vaughn, M. V. (2005). Performing Blackness on English Stages, 1500-1800. Cambridge: Cambridge U.P.

Vaughn, M. V. (2011). Supersubtle Venetians: Richard Knolles and the Geopolitics of Shakespeare's Othello. In Visions of Venice in Shakespeare (pp. 19-32). Ashgate: Surrey.

Vitkus, D. (1997). Turning Turks in Othello: The Conversion and Damnation of the Moor. Shakespeare Quarterly, 48(2), 145-176. https://doi.org/10.2307/2871278

Wangh, M. (1950). Othello: The Tragedy of Iago. The Psychoanalytic Quarterly, 19(2), 202-212. https://doi.org/10.1080/21674086.1950.11925798

Wells, S. (2011). Foreword. In L. Tosi \& S. Bassi (Eds.), Vision of Venice in Shakespeare (pp. xv-xviii). Ashgate: Surrey.

\section{Copyrights}

Copyright for this article is retained by the author, with first publication rights granted to the journal.

This is an open-access article distributed under the terms and conditions of the Creative Commons Attribution license (http://creativecommons.org/licenses/by/4.0/). 